\title{
EVALUATION OF A NEW PRESERVED LATEX ANTIGEN FOR THE SERO-DIAGNOSIS OF RHEUMATOID ARTHRITIS*
}

\author{
BY \\ M. GOLDIN AND ARNOLD BLACK \\ From the Department of Pathology, Division of Microbiology, and the Department of Medicine, \\ Mount Sinai Hospital, and The Chicago Medical School, Chicago, Illinois
}

Serological procedures useful for the detection of rheumatoid factors, utilizing polystyrene latex particles, have become well established and show a reasonably good degree of specificity and sensitivity (Mayne and Mathieson, 1961; Plotz and Singer, 1956; Vaughan, 1959). The use of these tests has been reviewed by Singer (1961) and Waller, Decker, Toone, and Irby (1961). The tests have also been found of value in studying patients with nonrheumatic diseases (Atwater and Jacox, 1963; Caplan, 1963; Dresner and Trombly, 1959; Howell, Malcolm, and Pike, 1960). Many modifications of the original Singer and Plotz Fraction II Latex Particle (F-II L.P.) method (Singer and Plotz, 1956) have been reported, both slide and test tube (Bird and Burr, 1962; Rheins, McCoy, Buehler, and Burrell, 1957a; Singer and Plotz, 1958a, b). The F-II L.P. procedure uses polystyrene latex particles (Dow, $0.81 \mu$ in diameter) sensitized with human gamma globulin (Fraction II) in an alkaline buffer. Rheins, McCoy, Burrell, and Buehler (1957b) showed that gamma globulin from seven animal species, including bovine, could be used in place of human gamma globulin. Burby and Behr (1958) found that Dow $0.81 \mu$ particles sensitized with bovine globulin were as satisfactory for this test as were those sensitized with human gamma globulin, and the same authors (1959) also reported that a new polystyrene latex particle manufactured in Great Britain gave results equivalent to those obtained with the Dow particles, if used in a different dilution. Payne (1961) described a new procedure using the British latex particles sensitized with bovine gamma globulin in an alkaline buffer. He claimed that his procedure showed good agreement with the sensitized sheep cell agglutination test (Jacobson, Kammerer, Wolf, Epstein, and Heller,

* Aided in part by a grant from the Illinois Chapter, Arthritis and Rheumatism Foundation.
1956) and F-II L.P. tests, and was technically simpler.

Recently, we have prepared a new preserved concentrated antigen for the detection of rheumatoid factor in serum. This antigent is prepared from polystyrene latex particles+, similar to those used by Payne (1961), sensitized with bovine gamma globulin. The advantages claimed for this antigen are that it is economical, stable, and simple to use, and an evaluation was therefore conducted to compare this material with other widely used latex procedures in the sero-diagnosis of rheumatoid factor.

\section{Methods}

Blood samples were collected from patients and each of the tests described was performed within 24 hours of collection, with few exceptions. The following techniques were performed on each serum:

(1) RA slide test (Hyland) according to the manufacturer's directions.

(2) Eosin latex slide test (Singer and Plotz, 1958b) using 1 per cent. and 2 per cent. eosin. Agglutination in either dilution of eosin was considered positive.

(3) F-II L.P. using human gamma globulin and Dow 0.81 $\mu$ particles (Singer and Plotz, 1956). Tubes were incubated at $56^{\circ} \mathrm{C}$. for $2 \mathrm{hrs}$, refrigerated overnight, and centrifuged at 2300 r.p.m. for $3 \mathrm{~min}$. Agglutination in a dilution of $1: 160$ or higher was considered as positive.

(4) Preserved antigen-Sera were diluted serially in glycine-saline buffer, $\mathrm{pH} 8 \cdot 2 \S$ from $1: 20$ to $1: 2560$ in $1 \mathrm{ml}$. amounts in scrupulously clean, unscratched $10 \times 75 \mathrm{~mm}$. test tubes. Inactivation of the serum was found to be unnecessary, but heating the serum at $56^{\circ} \mathrm{C}$. for $15 \mathrm{~min}$. occasionally gave somewhat sharper end-points.

+ Details of the preparation of this reagent are to be published. + Colabtex, Colab Laboratories, Inc., Chicago Heights, Illinois.

$\$ 975 \mathrm{ml} .0 .1 \mathrm{M}$ glycine and $2.5 \mathrm{ml}$. $1 \mathrm{~N} \mathrm{NaOH}$ made up to 1 litre with distilled water and the $\mathrm{pH}$ adjusted to $8 \cdot 2$. $10 \mathrm{gr}$. sodium with distilled water and the $\mathrm{pH}$ 
The antigen was thoroughly shaken and diluted $1: 10$ with the buffer, and $1 \mathrm{ml}$. was added to each tube.

The tubes were well mixed and allowed to stand at room temperature overnight. Tubes were then read in an oblique light against a dark background. Tubes which showed complete sedimentation of the latex particles, or macroscopically discrete particles in suspension were considered positive. Negative tubes were those that remained uniformly milky and showed no agglutination. The titre was considered as the last initial serum dilution showing distinct agglutination. A titre of 1:40 or greater was considered positive by this method.

Titrations were also performed in plastic "Perspex" plates, $5 \frac{1}{2} \times 7 \frac{1}{16}$ in. with eighty wells $\frac{5}{8}$ in. in diameter, ${ }^{*}$ in an identical manner, except the final volume in each well was $1 \mathrm{ml}$. Readings were done by placing the plates against a dark background with a strong direct light. The end-point was considered to be the last dilution of serum showing distinctly visible macroscopic agglutination in the bottom of the well.

\section{Patients}

The patients tested were divided into the following groups:

Group I.-Patients with a clinical diagnosis of peripheral rheumatoid arthritis, classical or definite, according to the criteria of the American Rheumatism Association (1964).

Group II.-Patients with rheumatic diseases other than peripheral rheumatoid arthritis, including osteo-arthritis, septic arthritis, gout, and ankylosing spondylitis.

Group III.-Patients with a clinical diagnosis of collagen disease, including systemic lupus erythematosus, dermatomyositis, and sarcoidosis.

Group IV.-Patients with various non-rheumatic disease entities and dysproteinaemias.

Group V.-Normal healthy subjects-blood donors, students, and employees.

\section{Results and Discussion}

The results are set out in detail in Table I.

In Group I (rheumatoid arthritis) complete agreement between the F-II L.P. and the preserved antigen was found in 84 of 92 patients ( 91 per cent.)

In Group II (arthritis other than rheumatoid) agreement was found in 93 per cent).

In Group III (collagen diseases) in 79 per cent).

In Group IV (non-arthritic diseases) in 100 per cent.

In Group V (normal) in 100 per cent.

\footnotetext{
* Instrumentation Associates, Inc., 17 W. 60th St., New York, N.Y.
}

TABLE I

COMPARISON OF RESULTS WITH FOUR LATEX PROCEDURES IN FIVE GROUPS OF PATIENTS

\begin{tabular}{|c|c|c|c|c|c|c|}
\hline & & & \multicolumn{4}{|c|}{ Tests } \\
\hline Group & & & $\begin{array}{l}\text { R.A. } \\
\text { Slide }\end{array}$ & $\begin{array}{l}\text { Eosin } \\
\text { Slide }\end{array}$ & F-II L.P. & $\begin{array}{l}\text { Preserved } \\
\text { Latex } \\
\text { Antigen }\end{array}$ \\
\hline I & 92 & $\begin{array}{r}77 \\
2 \\
1 \\
2 \\
3 \\
1 \\
6\end{array}$ & $\begin{array}{l}+ \\
+ \\
+ \\
+ \\
- \\
- \\
-\end{array}$ & $\begin{array}{l}+ \\
+ \\
+ \\
+ \\
+ \\
- \\
-\end{array}$ & $\begin{array}{l}+ \\
+ \\
- \\
- \\
+ \\
+ \\
-\end{array}$ & $\begin{array}{l}+ \\
- \\
- \\
+ \\
+ \\
- \\
-\end{array}$ \\
\hline II & 44 & $\begin{array}{r}2 \\
2 \\
1 \\
5 \\
1 \\
33\end{array}$ & $\begin{array}{l}+ \\
+ \\
+ \\
+ \\
- \\
-\end{array}$ & $\begin{array}{l}+ \\
+ \\
+ \\
- \\
- \\
-\end{array}$ & $\begin{array}{l}+ \\
- \\
- \\
- \\
+ \\
-\end{array}$ & $\begin{array}{l}+ \\
+ \\
- \\
- \\
-\end{array}$ \\
\hline III & 29 & $\begin{array}{r}5 \\
3 \\
2 \\
3 \\
16\end{array}$ & $\begin{array}{l}+ \\
+ \\
+ \\
+ \\
-\end{array}$ & $\begin{array}{l}+ \\
+ \\
- \\
+ \\
-\end{array}$ & $\begin{array}{l}+ \\
- \\
+ \\
-\end{array}$ & $\begin{array}{l}+ \\
+ \\
- \\
- \\
-\end{array}$ \\
\hline IV & 107 & $\begin{array}{r}1 \\
1 \\
1 \\
2 \\
102\end{array}$ & $\begin{array}{l}+ \\
+ \\
+ \\
- \\
-\end{array}$ & $\begin{array}{l}+ \\
+ \\
+ \\
+\end{array}$ & $\begin{array}{l}+ \\
- \\
- \\
-\end{array}$ & $\begin{array}{l} \pm \\
- \\
- \\
-\end{array}$ \\
\hline V & 80 & $\begin{array}{r}1 \\
1 \\
78\end{array}$ & $\begin{array}{l}+ \\
+ \\
-\end{array}$ & $\begin{array}{l}+ \\
-\end{array}$ & $\begin{array}{l}- \\
- \\
-\end{array}$ & $\begin{array}{l}- \\
-\end{array}$ \\
\hline
\end{tabular}

Comparative results between these two tests are shown in Table II.

TABLE II

COMPARISON OF LATEX TEST RESULTS

\begin{tabular}{|c|c|c|c|c|}
\hline \multirow{2}{*}{\multicolumn{3}{|c|}{ Preserved Latex Antigen }} & \multicolumn{2}{|c|}{ F-II L.P. } \\
\hline & & & Positive' & Negative \\
\hline Positive* & $\ldots$ & $\ldots$ & 88 & 7 \\
\hline Negative & $\ldots$ & $\ldots$ & 6 & 251 \\
\hline
\end{tabular}

* Agglutination in dilutions of $1: 40$ or higher.

+ Agglutination in dilutions of $1: 160$ or higher.

The RA and eosin slide tests showed excellent agreement in 98, 88, 93, 97, and 98 per cent. respectively (Table I), thus confirming the observations of Lane and Decker (1960), Caplan (1960, 1963), and Bianchi and Keech (1963).

A comparison of the titres obtained with the two latex tests is shown in Table III (opposite); the titres are uniformly higher with the F-II L.P. than with the preserved antigen. This numerical difference in titre, of course, offers no advantage as long as the same technique is adhered to throughout.

Stability studies on the preserved antigen were done by taking aliquots of positive sera and storing them in the deep freeze. The titres of the serum were then determined at intervals with the same lot of antigen stored in the refrigerator for 9 months. The stability of the preserved antigen was quite satisfactory (Table IV, opposite); the insignificant 
TABLE III

COMPARISON OF TITRES IN F-II L.P. AND PRESERVED LATEX TESTS

\begin{tabular}{|c|c|c|c|c|c|c|c|c|}
\hline \multirow{2}{*}{$\begin{array}{l}\text { Preserved Latex } \\
\text { Antigen Titres* }\end{array}$} & \multicolumn{8}{|c|}{ F-II L.P. Titres* } \\
\hline & $<160$ & 160 & 320 & 640 & 1280 & 2560 & 5120 & $>5120$ \\
\hline $\begin{array}{r}<40 \\
40 \\
80 \\
160 \\
320 \\
640 \\
1280 \\
2560 \\
>2560\end{array}$ & $\begin{array}{r}251 \\
4 \\
2 \\
1\end{array}$ & $\begin{array}{l}2 \\
2\end{array}$ & $\begin{array}{l}2 \\
2 \\
3 \\
1\end{array}$ & $\begin{array}{l}2 \\
4 \\
1 \\
4 \\
3\end{array}$ & $\begin{array}{l}3 \\
7 \\
7 \\
2 \\
3\end{array}$ & $\begin{array}{l}1 \\
6 \\
1\end{array}$ & $\begin{array}{r}2 \\
1 \\
2 \\
4 \\
11 \\
6 \\
9\end{array}$ & $\begin{array}{l}1 \\
2 \\
2 \\
1 \\
1\end{array}$ \\
\hline
\end{tabular}

* Reciprocal of final dilution of serum.

TABLE IV

STABILITY OF PRESERVED LATEX ANTIGEN

\begin{tabular}{|c|c|c|c|c|c|c|c|c|}
\hline \multirow{2}{*}{ Serum No. } & \multirow{2}{*}{ Antigen Lot No. } & \multirow{2}{*}{ Original Titre } & \multicolumn{6}{|c|}{ Titre after Storage at $+4^{\circ} \mathrm{C}$. (days) } \\
\hline & & & 30 & 60 & 90 & 120 & 180 & 270 \\
\hline 1 & $\begin{array}{l}\text { A-1 } \\
\text { A-2 } \\
\text { A-3 }\end{array}$ & $\begin{array}{l}320 \\
320 \\
320\end{array}$ & $\begin{array}{l}320 \\
320 \\
320\end{array}$ & $\begin{array}{l}320 \\
320 \\
160\end{array}$ & $\begin{array}{l}160 \\
320 \\
320\end{array}$ & $\begin{array}{l}320 \\
320 \\
320\end{array}$ & $\begin{array}{l}320 \\
320 \\
320\end{array}$ & $\begin{array}{l}160 \\
320 \\
320\end{array}$ \\
\hline 2 & $\begin{array}{l}A-1 \\
A-2 \\
A-3\end{array}$ & $\begin{array}{l}80 \\
80 \\
40\end{array}$ & $\begin{array}{l}80 \\
80 \\
40\end{array}$ & $\begin{array}{l}80 \\
80 \\
40\end{array}$ & $\begin{array}{l}80 \\
40 \\
40\end{array}$ & $\begin{array}{l}40 \\
80 \\
80\end{array}$ & $\begin{array}{l}40 \\
80 \\
40\end{array}$ & $\begin{array}{l}40 \\
80 \\
40\end{array}$ \\
\hline 3 & $\begin{array}{l}\text { A-1 } \\
\text { A-2 } \\
\text { A-3 }\end{array}$ & $\begin{array}{l}160 \\
160 \\
160\end{array}$ & $\begin{array}{l}160 \\
160 \\
160\end{array}$ & $\begin{array}{l}160 \\
160 \\
160\end{array}$ & $\begin{array}{r}160 \\
160 \\
80\end{array}$ & $\begin{array}{l}160 \\
160 \\
160\end{array}$ & $\begin{array}{r}80 \\
320 \\
160\end{array}$ & $\begin{array}{l}160 \\
160 \\
160\end{array}$ \\
\hline 4 & $\begin{array}{l}\text { A-1 } \\
\text { A-2 } \\
\text { A-3 }\end{array}$ & $\begin{array}{l}640 \\
640 \\
640\end{array}$ & $\begin{array}{l}640 \\
640 \\
640\end{array}$ & $\begin{array}{l}640 \\
320 \\
640\end{array}$ & $\begin{array}{l}640 \\
640 \\
640\end{array}$ & $\begin{array}{l}640 \\
640 \\
640\end{array}$ & $\begin{array}{l}640 \\
640 \\
640\end{array}$ & $\begin{array}{l}640 \\
640 \\
640\end{array}$ \\
\hline $5-10$ & $\begin{array}{l}\text { A-1 } \\
\text { A-2 } \\
\text { A-3 }\end{array}$ & $\begin{array}{l}\mathbf{0} \\
\mathbf{0} \\
\mathbf{0}\end{array}$ & $\begin{array}{l}\mathbf{0} \\
\mathbf{0} \\
\mathbf{0}\end{array}$ & $\begin{array}{l}\mathbf{0} \\
\mathbf{0} \\
\mathbf{0}\end{array}$ & $\begin{array}{l}\mathbf{0} \\
\mathbf{0} \\
\mathbf{0}\end{array}$ & $\begin{array}{l}\mathbf{0} \\
\mathbf{0} \\
\mathbf{0}\end{array}$ & $\begin{array}{l}\mathbf{0} \\
\mathbf{0} \\
\mathbf{0}\end{array}$ & $\begin{array}{l}\mathbf{0} \\
\mathbf{0} \\
\mathbf{0}\end{array}$ \\
\hline
\end{tabular}

differences in titre are probably due to pipetting inaccuracies rather than deterioration of the antigen.

The use of the new preserved antigen seems to offer the following advantages:

(1) No zoning effect was encountered, contrary to the F-II L.P. (Schubart, Cohen, and Calkins, 1959).

(2) The tests are extremely simple to perform and there is less waste of reagents. No special equipment is required, thus making it suitable for laboratories with limited facilities. If the "Perspex" plates are used, the amount of glassware required is minimal. The use of bovine rather than human gamma globulin is more economical.

(3) The results are easy to read and the antigen is stable for at least 9 months.

(4) The results are reproducible and less subject to error; they appear to be as sensitive as the more cumbersome F-II L.P. and more specific than the slide tests. As a screening test for other conditions (liver disease, hypergammaglobulinaemia, sarcoidosis, etc.), a more sensitive reaction, such as the eosin slide test would probably be more suitable (Atwater and Jacox, 1963; Caplan, 1960; Caplan, 1963; Bianchi and Keech, 1963). Few positive reactions were found in this series in non-rheumatic diseases.

\section{Summary}

Experience with a new concentrated preserved latex antigen for use in quantitative testing for rheumatoid factor is described. A comparison of the new antigen with two widely-used slide tests and the F II latex tube test shows it to be satisfactorily specific and sensitive. The advantages of this new antigen are discussed.

\section{REFERENCES}

American Rheumatism Association (1964). Bull. rheum. Dis., 14, 339.

Atwater, E. C., and Jacox, R. F. (1963). Ann. intern. Med., 58, 419. 
Bianchi, F., and Keech, M. K. (1963). J. Amer. med. Ass., 185, 318.

Bird, R., and Burr, R. G. (1962). J. clin. Path., 15, 472.

Burby, G., and Behr, G. (1958). Lancet, 2, 1157. (1959. Ibid, 1, 1209.

Caplan, H. I. (1960). Bull. Tufts New Engl. med. Cent., 6, 136.

(1963). Ann. intern. Med., 59, 449.

Dresner, E., and Trombly, P. (1959). New Engl. J. Med., 261, 981 .

Howell, D. S., Malcolm, J. M., and Pike, R. (1960). Amer.J. Med., 29, 662.

Jacobson, A. S., Kammerer, W. H., Wolf, J., Epstein, W. V., and Heller, G. (1956). Ibid, 20, 490.

Lane, J. J., and Decker, J. L. (1960). J. Amer. med. Ass., $173,982$.

Mayne, J. G., and Mathieson, D. R. (1961). Proc. Mayo Clin., 36, 365.

Payne, R. B. (1961). J. clin. Path., 14, 309.

Plotz, C. M., and Singer, J. M. (1956). Amer. J. Med., 21, 893.

Rheins, M. S., McCoy, F. W., Buehler, E. V., and Burrell, R. G. (1957a). Proc. Soc. exp. Biol. (N.Y.), 96, 67.

,-- , Burrell, R. G., and Buehler, E. V. (1957b). J. Lab. clin. Med., 50, 113.

Schubart, A. F., Cohen, A. S., and Calkins, E. (1959). New Engl. J. Med., 261, 363.

Singer, J. M. (1961). Amer. J. Med., 31, 766.

and Plotz, C. M. (1956). Ibid, 21, 888.

- (1958a). J. Amer. med. Ass., 168, 180.

Singer, J. M. and Plotz, C. M. (1958b). Arthr. and Rheum., 1, 142.

Vaughan, J. H. (1959). Amer. J. Med., 26, 596.

Waller, M. V., Decker, B., Toone, E. C., Jr., and Irby, R. (1961). Arthr. and Rheum., 4, 579.

\section{Evaluation d'un nouveau antigène au Latex, conservé, pour le sérodiagnostic de l'arthrite rhumatismale}

\section{RÉSUMÉ}

On décrit les expériences avec un nouveau antigène au Latex concentré et conservé, appliqué aux tests quantitatifs dans la détermination du facteur rhumatoïde. La comparaison de ce nouveau antigène avec deux tests usuels sur lames et avec le test au Latex F II en éprouvette montre qu'il est sensible et bien spécifique. On discute les avantages de ce nouveau antigène.

\section{Valoración de un nuevo antígeno sobre Latex, conservable, en el serodiagnóstico de la artritis reumatoide}

Sumario

Se describe la investigación de un nuevo antigeno sobre Latex, concentrado y conservable, empleado en los tests cantitativos para determinar el factor reumatoide. La comparación de este nuevo antígeno con dos tests, en uso general, sobre portaobjetos y con el test sobre Latex F II en tubo mostró su especificidad satisfactoria y su sensibilidad. Se discuten las ventajas de este nuevo antígeno. 